\title{
From Hypatia to Victor Hugo to Larry and Sergey: 'All the world's knowledge' and universal authors' rights
}

\author{
British Academy Law Lecture \\ read 11 December 2012 \\ JANE C. GINSBURG \\ Fellow of the Academy
}

Abstract: Access to 'all the world's knowledge' is an ancient aspiration; a less venerable, but equally vigorous, universalism strives for the borderless protection of authors' rights. Late 19th-century law and politics brought us copyright universalism; 21st-century technology may bring us the universal digital library. But how can 'all the world's knowledge' be delivered, on demand, to users anywhere in the world (with Internet access), if the copyrights of the creators and publishers of many of those works are supposed to be enforceable almost everywhere in the world? Does it follow that the universal digital library of the near future threatens copyright holders? Or are libraries the endangered species of the impending era, as publishers partner with forprofit Internet intermediaries to make books ubiquitously available? Does accesstriumphalism therefore risk giving us not the universal digital library, but the universal digital bookstore? And, whether libraries or commercial intermediaries offer access, how will the world's authors fare?

Keywords: authorship, copyright, digital libraries, orphan works, universalism, utopianism

\section{INTRODUCTION}

Access to 'all the world's knowledge' is an ancient aspiration; a less venerable, but equally vigorous, universalism strives for the borderless protection of authors' rights. Late 19th-century law and politics implemented copyright universalism; 21st-century technology may bring us the universal digital library, and with it a clash of utopian yearnings, if culture freely accessed comes to mean culture unremunerated. Does the 
universal digital library of the near future threaten copyright holders, particularly book publishers? Lest we sound too soon the dirge for traditional publishers and newer commercial distribution intermediaries, we should remember that digital media may enhance 'access to culture', but culture freed from its former masters may yet not be 'free'. Access-triumphalism may bring us not the universal digital library but the universal digital bookstore.

In this essay, I will first evoke two utopian goals: universal access to knowledge, and universal authors' rights. The former implied a curator-custodian, a public institution that would gather, systematise and make available the world's knowledge. The latter enforced private prerogative through the international recognition of authors' property rights that arise from their creativity or that are justified by the public benefits those creations bestow. Despite occasional skirmishes between copyright owners and libraries - think of the long resistance of some members of the Stationers' Company to depositing copies in the libraries designated by section 5 of the 1710 Statute of Anne - custodians and creators of knowledge long pursued complementary aims. That now may be changing. In the last part of this talk, I will address the clash of utopias epitomised by the Google book-scanning program and the legal responses it has inspired. Finally, as we query whether, through mass digitisation, libraries will replace publishers, or vice-versa, we should not lose sight of the authors, who are both copyright's raison d'etre and the necessary forebears of libraries, for without works of authorship to stock the collection, there is nothing to curate.

\section{ACCESS TO KNOWLEDGE UTOPIANISM: THE ALEXANDRIAN IMPETUS}

Let's start with a Cook's tour of custodians and curators, from the Library of Alexandria (whence the title of this talk's invocation of Hypatia ${ }^{2}$ ), to the Renaissance and the late 19th century, to new technologies of the 20th century, culminating in the Digital Public Library of America. ${ }^{3}$

Utopian dreams of a universal archive of knowledge almost always refer to the Library of Alexandria. It is often described as a 'universal library'. ${ }^{4}$ According a 2nd-century BC document from the Jewish community of Alexandria, its mission was

\footnotetext{
${ }^{1}$ Feather (1994: 100-19); Partridge (1938: 33-59).

${ }^{2}$ For a lively account of the life of, and literary tradition surrounding, the Alexandrian mathematician and philosopher — in fact, the earliest well-documented woman mathematician—see Dzielska (1995).

${ }^{3}$ For a more extensive survey, see, e.g. Wayne Bivens-Tatum (2012: 141-83).

${ }^{4}$ e.g. Canfora (1989: 20); Barnes (2000: 63). See also Johns (2009: 216) ('The ideal of the universal library has a long history, extending back to the Library of Alexandria and forward to utopian versions of the Internet').
} 
'To collect . . all the books in the world. ${ }^{5}$ Commentators throughout antiquity and early Christianity similarly evoked the comprehensive aspirations of the library. The American classicist and historian Roger Bagnall has described the persistent power of the idea of the Library of Alexandria:

[T] he Library of Alexandria bequeathed the image of itself, the idea of a large, comprehensive library embracing all of knowledge. ... The Library ... appealed to the imagination of all who wrote about it. Its grip on the minds of all who contemplated it was already in antiquity as great as it was later, and it hardly mattered what fanciful numbers they used to express its greatness. Although the authors whose works survived antiquity told posterity little of any concrete substance about the Library, they transmitted its indelible impression on their imaginations. ${ }^{6}$

Moving ahead some 1,500 years, with the advent of the printing press and the vast increase in the range of books, new and old, that it enabled, no single place could unite all literary and scientific productions. The urge to comprehensive knowledge did not abate, however. Rather it spawned a new kind of collection and systematisation, the thematic catalogue. ${ }^{7}$ For example, in 1550 the Florentine man of letters and bibliographer Anton Francesco Doni published in Venice his Libraria, subtitled 'in which are inscribed all the vernacular authors with one hundred discussions of them [as well as] all the translations made from other languages into ours, and an index generally laid out according to the customs of booksellers' ${ }^{8}$

Doni seems to have become obsessed with his task, for a subsequent printing from 1550 tells us that it is 'newly reprinted, corrected, and with many things added that were missing'. ${ }^{9}$ In 1557 the indefatigable Doni produced a second edition, featuring an even more prolix subtitle, informing us that his work now consists of three treatises, and stating that the second treatise includes Doni's more recent listings of the authors, the works, the titles and the substance, and that his book is 'necessary and useful to all those who need knowledge of [our] language, and wish to know how to write and think about all the authors, their books and their works'. ${ }^{10}$ The Libraria went through further editions, even following Doni's death, as successive publishers sought to satisfy a vigorous demand for this kind of compendium. Thus, a 1580 edition tacks on to Doni's run-on title the information that to the current printing 'have been added all the vernacular works published in the last 30 years in Italy'. However, in a punctilious

\footnotetext{
${ }^{5}$ So says the oldest known document referring to the Library, the 2nd-century BC Letter of Aristeas. Heller-Roazen (2002: 141).

${ }^{6}$ Bagnall (2002: 361).

${ }^{7}$ See Chartier (1993: 38-52).

${ }^{8}$ Doni (1550a).

${ }^{9}$ Doni (1550b).

${ }^{10}$ Doni (1557).
} 


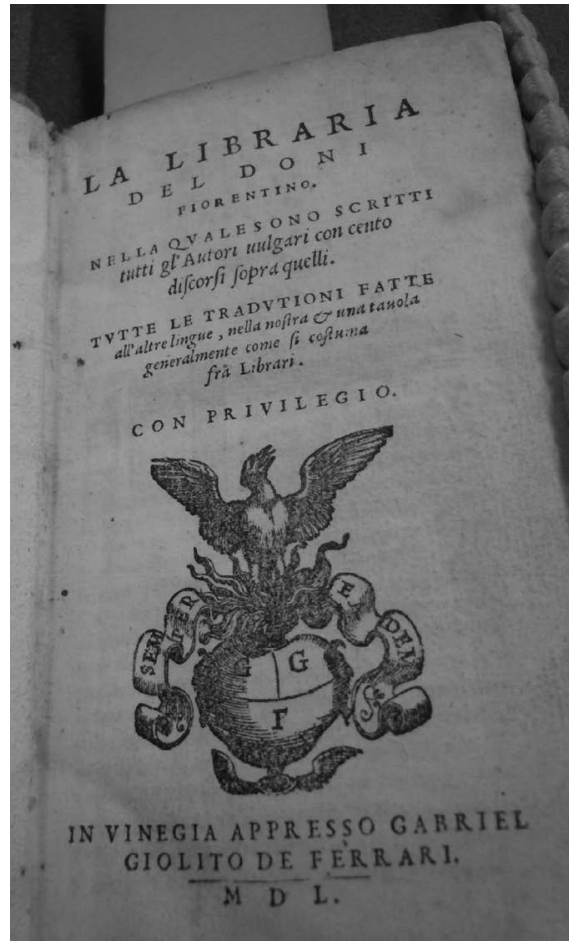

\section{LA LIBRARTA DEL DONI PIORENTINO,}

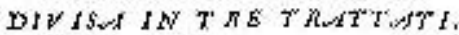

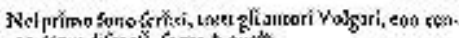

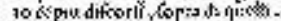

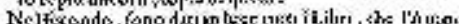

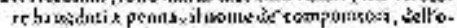

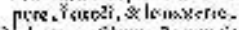

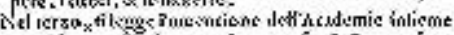

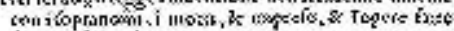
1.23uxtiglisesteluses.

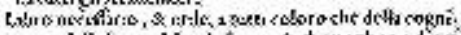

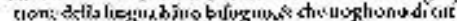

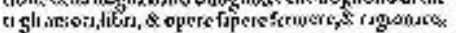

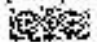

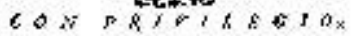

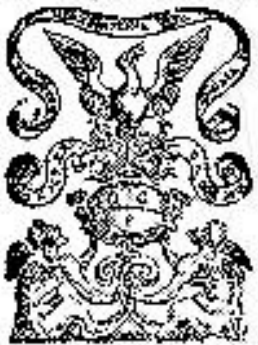

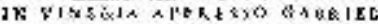

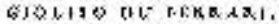

$x$ a $6: 1$ :

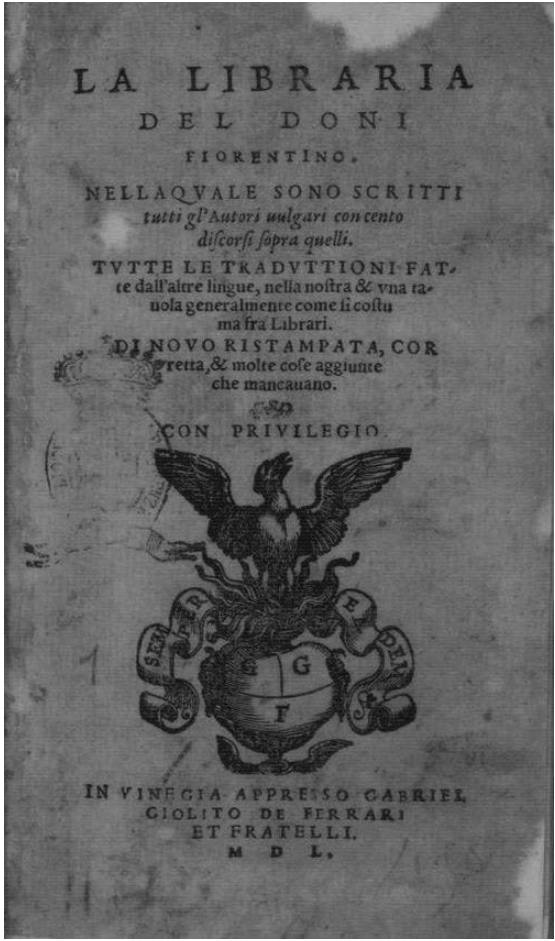

L A L I B R A R I A

D E L D O.N I FIORENTINO;

Neila quale fono. Scritti tutti gli Autori volgari, con cento difcorfi Sopra quelli;

Tutte le tradottioni fatte dall'altre lingue, nella noftra, \& vna tauola generale, come fi coltuma fra Librari.

Opera vilile a ciafouno che fo diletsa della lingua volgare, or che defidera fornire rno studio dilibri, composti in eff. lingusa;

Di núouo riftampata, \&agginntiui tutti i libri volgari gofti in luce da trenta anni in qua, \& leuatone sori tutti gli Autori, \& libri prohibtti.

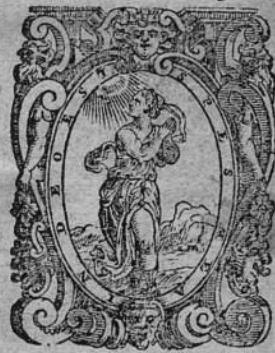

IN VINEGIA,

Preflo Altobello Salicato. M D L XXX.

Figure 1: 'All the authors': Doni's Libraria in its first two editions of 1550 and the editions of 1557 and 1580. (Sources: Photograph of first edition by Jane C. Ginsburg, from the Columbia University Rare Book Room; and EDIT16, Istituto Centrale per il Catalogo Unico delle biblioteche italiane e per le informazioni bibliografiche, available at http://edit16.iccu.sbn.it/web_iccu/ihome.htm). 


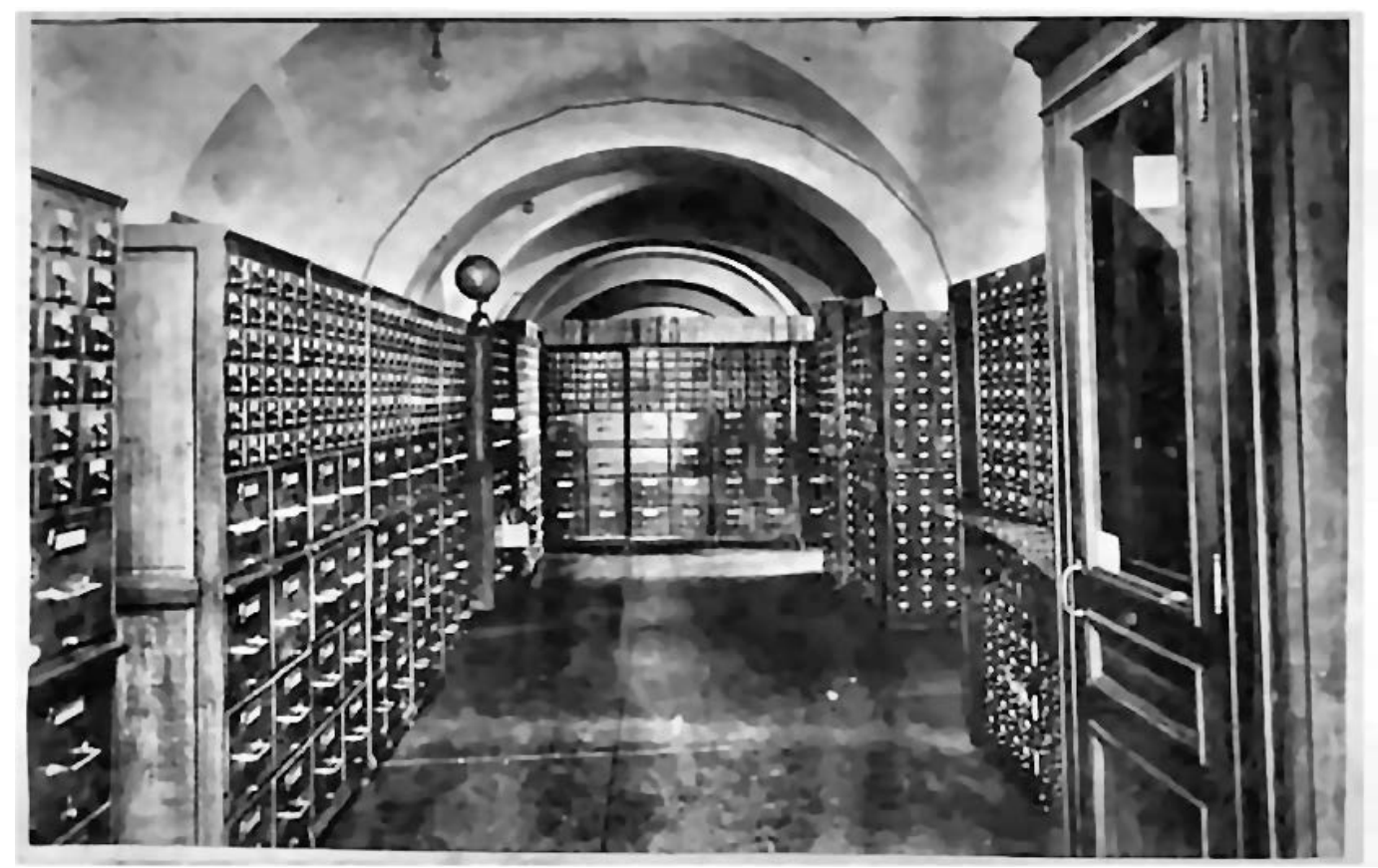

Figure 2: Paul Otlet's documentary project, in an undated photograph before World War I. (Source: Wouter Van Acker, 'Internationalist Utopias of Visual Education: The Graphic and Scenographic Transformation of the Universal Encyclopaedia in the Work of Paul Otlet, Patrick Geddes, and Otto Neurath', Perspectives on Science 19 (2011), http://muse.jhu.edu/journals/perspectives_on_science/ v019/19.1.van-acker.html\#fig13).

nod to the Counter-Reformation, the 1580 edition's subtitle also cautions 'and having removed all the prohibited authors and books'. ${ }^{11}$

We skip forward to the end of the 19th century where we encounter Belgian lawyer and visionary Paul Otlet, a spiritual descendant of Doni, but by a power of ten (at least). He imagined a 'Universal Book of Knowledge' in which:

[A]ll knowledge, all information could be so condensed that it could be contained in a limited number of works placed on a desk, therefore within hand's reach, and indexed in such a way as to ensure maximum consultability. In this case the World described in the entirety of Books would really be within everyone's grasp. The Universal Book created from all Books would become very approximately an annex to the Brain, a substratum even of memory, an external mechanism and instrument of the mind but so close to it, so apt to its use that it would truly be a sort of appended organ, an exodermic appendage.... This organ would have the function of making us 'ubiquitous and eternal'. ${ }^{12}$

\footnotetext{
${ }^{11}$ Doni (1580).

${ }^{12}$ Otlet (1934: 428). The translation is adapted from Raymond (1990: 1).
} 


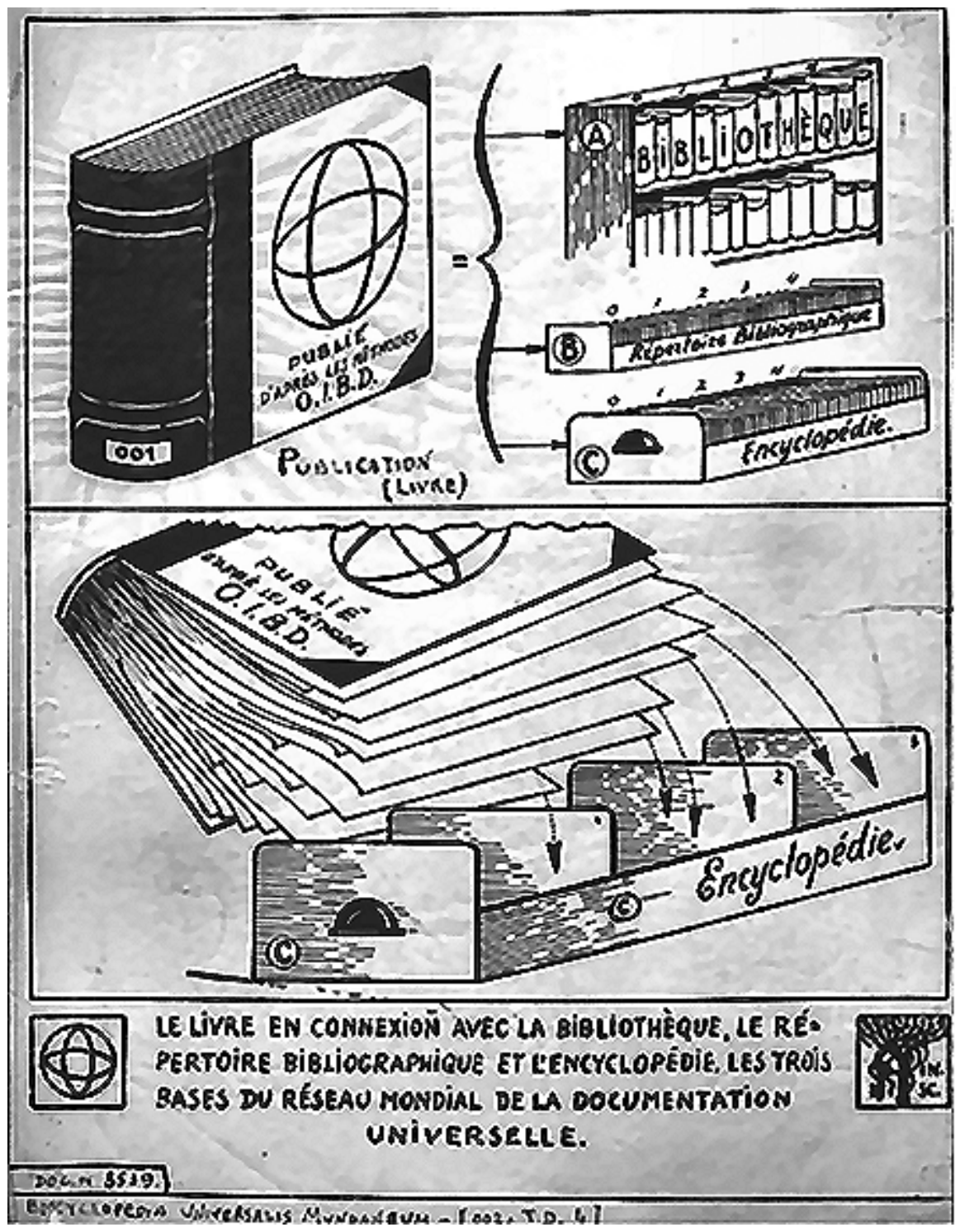

Figure 3: Paul Otlet was not only a visionary but a striking illustrator of his universalist projects. Here, the book is dissected into its components, transformed into documentation-perhaps to become a part of the 'Universal Book'. (Source: Charles van den Heuvel, 'Facing Interfaces: Paul Otlet's Visualizations of Data Integration', Journal of the American Society for Information Science and Technology, 62 (2011); 2313-2326.)

Sounds like science fiction, only today's futurists would house the information in an 'endo-dermic appendage', such as a brain-embedded microchip to which information could be uploaded, à la The Matrix. Otlet's frenzied efforts to capture and catalogue all the world's knowledge produced real information-processing innovations, too. $\mathrm{He}$ 
invented the great search tool of libraries of yore, the once-ubiquitous system of index card files on rods in pull-out drawers in library cabinets. And with over 12 million of those index cards he created an archive he called the Mundaneum, which he saw as a successor to the Library of Alexandria, the Summa of Aquinas, the Encyclopédie, and all the world's great libraries, museums and world expositions put together. We might perceive it as a kind of Google avant la lettre. Otlet declared that the Mundaneum 'is about gathering, condensing, classifying, coordinating . . . finally, to represent and to reproduce'. ${ }^{13}$ (The Mundaneum still exists physically in Mons, Belgium, and virtually at www.mundaneum.org. Perhaps fittingly, it benefits from Google's sponsorship.)

Otlet also co-invented microfilm, a new technology that far exceeded his principal bibliographic efforts. ${ }^{14}$ This new, convenient and compressed storage medium could enable libraries both to preserve fragile volumes and to increase their collections while occupying far less shelf space. With microfilm we go beyond summarising the contents of books to return to the original utopian aspiration of gathering all the world's books themselves. ${ }^{15}$ But at this point the visionaries address the possibility that all this content could come within the grasp not only of institutions but also of individuals. In 1945, Vannevar Bush - who, as the director of the wartime US Office of Scientific Research and Development, was one of the forces behind the Manhattan Projectcontemplated the revolutionary promise of microfilm. In a noted essay published in the Atlantic Monthly in the closing months of the Second World War, Bush proposed a 'memex', a private device for information storage and retrieval that, by responding to and storing the associations that the human mind produces, would transcend the

${ }^{13}$ Otlet (1935: 450) (translation mine).

${ }^{14}$ See Goldschmidt \& P. Otlet (1906), trans. in Raymond (1990: 87-95).

${ }^{15}$ Otlet and his fellow thinkers appear to have spared little thought for authors' rights, but the tension between microfilm universalism and copyright is apparent. In the 1930s, a member of the American Documentation Institute informed readers of the journal Science that scientific authors 'do not desire [copyright] protection and it is certainly rarely possible for the publishers to benefit from it' and that it is 'not clear why any publication of scientific research is ever copyrighted'. Therefore, copyright 'should have little weight in appraising the tremendous service which microfilm copying in libraries can contribute to the advancement of learning' (Seidell 1939: 219-20). While Seidell's sentiment regarding the relative weights of private and public interests in scientific communication will ring a familiar tone to those following the current open-access debate in academic research communities, sweeping propositions that scientific authors lack proprietary interests are probably overstated. Moreover, subsequent events have completely belied Seidell's surmise that publishers rarely benefit from scientific research.

As an exception to the exclusive rights of authors, US copyright law accommodates library reproduction and distribution, including by microfilm (and now by digital copying), but only under narrow circumstances (such as for preservation purposes) and in small quantities. See 17 U.S.C. § 108. One commentator observes that microfilming for preservation purposes raised 'few copyright issues' in its heyday due to the shorter copyright term prevalent before the 1976 revision of the Copyright Act. (Gasaway 2003: 648). 


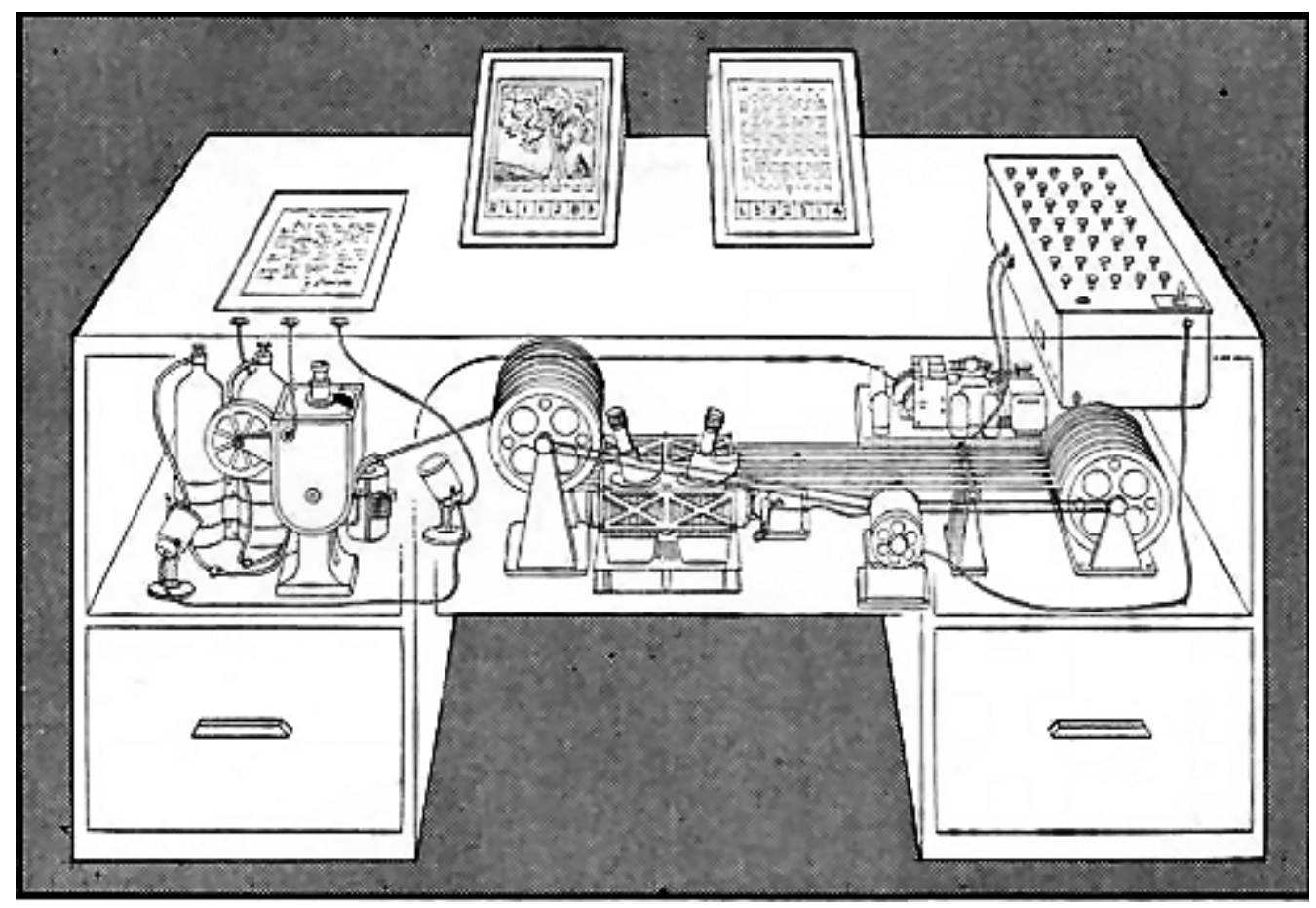

Figure 4: Vannevar Bush's 'memex', as imagined in the 10 September 1945 edition of Life magazine. (Source: Google's Life archive, http://books.google.com/books?id=uUkEAAAAMBAJ\&lpg=PP1\&dq= memex\&pg $=\mathrm{PA} 123 \# \mathrm{v}=$ onepage $\& \mathrm{q} \& \mathrm{f}=$ false. $)$

'artificiality of systems of indexing' used in libraries. ${ }^{16}$ Bush described the device and its capacities as follows:

A memex is a device in which an individual stores all his books, records, and communications, and which is mechanized so that it may be consulted with exceeding speed and flexibility. It is an enlarged intimate supplement to his memory. ${ }^{17}$

Note the 'memory supplements' metaphor recalling the Otlet-ian 'exodermic appendage' of the mind. Mechanical storage adjuncts to the brain join the Library of Alexandria as a top trope for the bibliographically inclined. Bush continued:

It consists of a desk, and while it can presumably be operated from a distance, it is primarily the piece of furniture at which he works. On the top are slanting translucent screens, on which material can be projected for convenient reading. There is a keyboard, and sets of buttons and levers. Otherwise it looks like an ordinary desk.

\footnotetext{
${ }^{16}$ Bush (1945: 106).

${ }^{17}$ Ibid., pp. 106-7.
} 
In one end is the stored material. The matter of bulk is well taken care of by improved microfilm. Only a small part of the interior of the memex is devoted to storage, the rest to mechanism. Yet if the user inserted 5000 pages of material a day it would take him hundreds of years to fill the repository, so he can be profligate and enter material freely. ${ }^{18}$

From the photographic impressions of microfilm to today's digital scanning, the prospects for the great and universally accessible compendium of content are en route to realisation. Indeed, Harvard University librarian and renowned historian of the book, Robert Darnton, last year announced the April 2013 launch of the Digital Public Library. At a lecture at Columbia Law School in April 2012, Darnton declared: 'We know that we want the DPLA to serve a broad constituency: not just faculty in research universities but students in community colleges, ordinary readers, K-through-12 school children and seniors in retirement communities-anyone and everyone with an interest in books. ${ }^{19}$ Darnton is confident that the DPLA will overcome any technological and funding impediments. There remains one stumbling block: many of those interesting books are still under copyright, and sorting through the rights clearance may prove daunting if not intractable. But we will return to those problems after we consider how copyright, with its own universalist aspirations, comes into the picture.

\section{COPYRIGHT UTOPIANISM: UNIVERSAL PROTECTION OF AUTHORS' RIGHTS}

Before copyright, the printing press gave rise to printing privileges, issued by territorial sovereigns to protect and encourage the investment in the material and labour of printing. But each sovereign's power to protect the nascent book trade extended only to the limits of its realm (or, for Venice, its Republic). Publishers-or authors, for authors, too, obtained privileges - who envisioned multi-territorial distribution would seek multiple privileges, for example, from the French king, the Holy Roman Emperor, and the various Italian principalities. But Papal privileges - over half of which appear to have been granted to authors in recognition of their labours and contributions to the public interest (and that of the Church) - defied territoriality; they purported to cover all of Christendom, and their sanctions included confiscation of infringing copies and automatic excommunication - a truly extraterritorial remedy. ${ }^{20}$

We are, however, in the 16th century, and the efficacy of excommunication may

\footnotetext{
${ }^{18}$ Ibid., p. 107.

${ }^{19}$ Darnton (2012: 16).

${ }^{20}$ See generally Ginsburg (2013).
} 
not have been what it once was. Even the Pope and the privilege-granting Cardinal Secretary of Papal Briefs probably would not have expected a new Canossa of legions of penitent infringers, barefoot in the snow, begging absolution and surrendering their pirate wares. So the cautious publisher or author, Ariosto among them, would have sought the prestige of a Papal privilege, but would also have continued to petition all likely sovereigns for the 'special grace' of an exclusive privilege prohibiting unauthorised printing, selling or importation of their works. ${ }^{21}$

By the 18th and 19th centuries, with the advent of true copyright law (that is, exclusive rights vesting in authors), exclusive rights are no longer a matter of 'special grace' but have become 'property upon the work's creation' rights justified by the author's intellectual labour, as well as by the interests of the polity. Notwithstanding the competing social contractarian concept of copyright, the rhetoric of property dominated the copyright debates in the nineteenth century, particularly on the European Continent, ${ }^{22}$ but even for some commentators in the United States. As Francis Lieber, a German émigré to the US, hopefully (and prematurely) wrote in 1840 in On International Copyright:

When [copyrights] had once been granted, the belief soon grew up as though [the statute laws] had first created this species of property; as though the whole title of property was ... the creature of grace, a thing made by society for some real or supposed benefit which it expects to derive from this gracious grant. ...

It is, however, cheering to observe, that universally, with the advance of political civilization and a clearer perception of individual rights, the acknowledgement of literary property has likewise advanced, and the true basis upon which its justice rests has been more and more clearly perceived in countries where the true ground had been lost sight of. ${ }^{23}$

Property rationales also fuelled the endeavours, starting in the mid-19th century, to achieve the goal of universal international protection of authors' rights. Rising literacy, both literary and musical, had by then contributed to an international market for works of authorship, but copyright owners still found their rights confined to national borders. Bilateral treaties arose to grant protection on the basis of reciprocity, but obtaining coverage for multiple territories remained complex and cumbersome. ${ }^{24}$ Composers particularly found themselves attempting multiple simultaneous 'first' publication in several countries in order to endow their works with local protection. International copyright concerns motivated Gilbert and Sullivan to arrange for the Pirates of Penzance to debut in New York City in 1879, as the US did not then protect

\footnotetext{
${ }^{21}$ Ginsburg (2013).

${ }^{22}$ See, e.g. Pfister (2005: 117-209).

${ }^{23}$ Lieber (1840: 21-2, 25).

${ }^{24}$ See Ricketson \& Ginsburg (2006: paras. 1.29-42).
} 
foreign works. Effective international protection required multinational cooperation, not only to recognise foreign works, but also to protect them on non-discriminatory terms. Ideally, those terms should be as uniform as possible across borders.

In 1858 the first great international congress on literary and artistic property took place in Brussels, with over 300 delegates, including Charles Dickens, John Stewart Mill, Eugène Scribe and Alphonse de Lamartine, among many other luminaries. It declared 'the principle that the national recognition of the authors' property in their works of literature and of art should be established in the laws of all civilized peoples'. ${ }^{25}$ Lest one think that copyright universalism also means 'copyright maximalism' - setting greedy copyright owners against the broader public interest - it is worth observing that the distinguished Belgian lawyer Charles Faider, who presided over the congress, also grandiloquently asserted the

necessity to proclaim as a fundamental principle, the uniform, universal and international recognition of intellectual property: the enjoyment of this property should be broadly guaranteed, but within reasonable limits, in order to pour into the common stock of human intelligence the treasures by which those elite spirits, after their temporary profit, receive forever the honour and the glory and the gratitude of mankind. ${ }^{26}$

The proceedings indicate that this declaration reaped great applause, as did his subsequent acknowledgement that the

fair exchange [of time-limited protection] is the debt of genius toward the multitude; I daresay it is the debt of genius toward glory itself, ... so that the masterpieces of the arts which civilize future generations shall be accessible to all without being costly for anyone. $^{27}$

Twenty years later, however, authors' rights remained bounded by national borders, freighted with formalities, and prey to international piracy. And so began another universalist push, propelled by the outsize celebrity of Victor Hugo, who presided over the 1878 International Literary Congress in Paris. This gathering, which also featured the participation of Ivan Turgenev, gave birth to the Association Litterraire et Artistique Internationale (ALAI), the principal moving force behind the 1886 Berne Convention and its subsequent revisions. ${ }^{28}$ The Berne Convention remains the preeminent multilateral copyright treaty and the predominant expression of copyright universalism..$^{29}$

Victor Hugo made several speeches in the course of the 1878 Congress, often at a

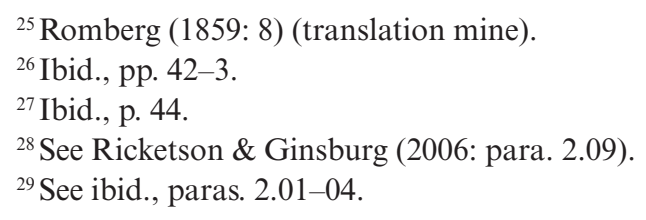


rather high level of abstraction, and an even higher level of oratory, about truth, beauty and civilisation, literature and human progress. But he also pronounced on copyright, in terms echoed today by scholars such as Graeme Austin who remind us that authors' rights are human rights. ${ }^{30}$ Victor Hugo declared:

Literary property is in the public interest. All the old monarchic laws have rejected, and continue to reject literary property. To what end? In order to enslave. The writer who is an owner [of his literary property] is a writer who is free. To take his property away is to deprive him of his independence. ${ }^{31}$

Like his predecessors in Brussels, Victor Hugo was a copyright universalist, but not an absolutist. 'Let us establish the principle of the respect of property; let us affirm literary property', he exclaimed, 'but, at the same time, let us also establish the public domain. ... If of the two rights, that of the writer and that of the human spirit had to be sacrificed, it would certainly be the right of the writer, for the public interest is our sole preoccupation, and the whole of the people, I declare, must come before us. ${ }^{32}$ As a result, while a few diehards were still militating for perpetual copyright control over works of authorship, Victor Hugo advocated an end to the author's exclusive right at death, followed by an indefinite 'domaine public payant'. ${ }^{33}$ Hugo believed that the direct heirs were entitled to an income from the author's work, but he was particularly suspicious of authors' heirs' communion with the intentions of their ancestors. Hence he warmly and repeatedly urged insulating the work from filial pretentions. It is therefore all the more ironic that, over 100 years later, a Hugo descendant attemptedultimately unsuccessfully — in the name of the artistic integrity of Hugo's oeuvre, to prevent the publication of other authors' purported sequels to Les Misérables. ${ }^{34}$

The 1878 congress voted several resolutions, including the declaration that ' $[\mathrm{t}] \mathrm{he}$ author's rights over his work constitutes not a grant made by law, but one of the forms of property that the legislator must guarantee'. ${ }^{35}$ The delegates also endorsed the 'domaine public payant' and the non-discrimination principle of treating foreign

\footnotetext{
${ }^{30}$ See generally Helfer \& Austin (2011); G.W. Austin \& A.G. Zavidow, 'Copyright Law Reform Through a Human Rights Lens', in P.L.C. Torremans (ed.), Intellectual Property and Human Rights (Alphen aan den Rijn, Netherlands, 2008), pp. 257-85.

${ }^{31}$ Société des Gens de Lettres de (1879: 106) (translation mine).

${ }^{32}$ Ibid., p. 107.

${ }^{33}$ See, e.g. Hugo's early remarks to the 1878 Congress: 'The law should give to all publishers the right to publish any book after the author's death, on the sole condition of payment to the direct heirs of a very small royalty that would not in any case exceed five to ten percent of net profits. This very simple system, which reconciles the writer's incontestable property right with the no less incontestable right of the public domain, has been recommended.' Ibid. (translation mine).

${ }^{34}$ See Société Plon SA v. Pierre Hugo, Cour de Cassation 1ère civ., decision of 30 Jan. 2007, Bull. civ. I, no. 47.

${ }^{35}$ Société des Gens de Lettres de France (1879: 369).
} 
authors as if they were local authors. The second of these propositions became a cornerstone of the Berne Convention; ${ }^{36}$ the first, albeit adopted in some national legislations, for example Italy's, has never become an international norm. ${ }^{37}$

The Berne Convention emerged in 1886 after three years of congresses pitting two competing conceptions of international copyright. Under one, more universalist, view, the convention would adopt a supranational copyright code, imposing uniform substantive norms on all member states. This approach had the merit of simplicity, but was politically unlikely, for it would have required member states to forgo distinctions derived from national cultural policies. The alternative, national treatment, ensured that foreign authors would be assimilated to local authors. Thus, within each member state, domestic and foreign authors would be subject to the same copyright law, but the substantive norms might differ from state to state. In the end, the Berne Convention combined the approaches, making national treatment the general base line (with certain exceptions), but specifying certain supranational standards of protection that member states would be obliged to accord to foreign authors, whatever the level of protection they granted to their own authors. Each successive revision conference added to the number of supranational norms, so that by the present day we have come close to an international copyright code, or at least an international copyright framing law, whose details member states fill in. ${ }^{38}$

For our purposes, tracing the development of universal authors' rights, perhaps the most important revision conference was the one held in Berlin in 1908. It established the dual principles of (1) absence of formalities conditioning the existence and enforcement of copyright, and (2) independence of international and domestic protection. ${ }^{39}$ Formalities, such as registration and/or publication of claims and/or national library deposit of copies, are conditions precedent to the existence or enforcement of copyright. In the 19th century, an author would have had to comply with the formalities of each country for which he sought protection - assuming the country of which the author was not a national extended any protection at all to foreign claimants. ${ }^{40}$ Proper

\footnotetext{
${ }^{36}$ Berne Convention for the Protection of Literary and Artistic Works, art. 5.

${ }^{37}$ And Italy has, indeed, done away with it. See Legge 22 aprile 1941, n. 633, art. 175-9, repealed by Decreto Legge 31 dicembre 1996, n. 669, art. 6. Some variant of the 'domaine public payant' remains law in several African countries and Paraguay. WIPO Intergovernmental Committee on Intellectual Property and Genetic Resources, Traditional Knowledge and Folklore, Note on the Meanings of the Term 'Public Domain' in the Intellectual Property System with Special Reference to the Protection of Traditional Knowledge and Traditional Cultural Expressions/Expressions of Folklore, WIPO/GRTKF/IC/17/INF/8 (24 Nov. 2010), http://www.wipo.int/edocs/mdocs/tk/en/wipo_grtkf_ic_17/wipo_grtkf_ic_17_inf_8.pdf, annex p. 12.

${ }^{38}$ See generally Ricketson \& Ginsburg (2006): paras. 2.01-04.

${ }^{39}$ Ibid., para. 3.12.

${ }^{40}$ See ibid., paras. 1.19, 1.40 .
} 
compliance was cumbersome, costly, and often unsuccessful, hence authors' demand as early as the 1858 Brussels Congress that authors be protected in all countries so long as they satisfied whatever formalities their home countries imposed. The 1886 and 1896 versions of the Berne Convention adopted this approach. ${ }^{41}$

But in practice, it turned out to be difficult to prove to foreign authorities that the author had complied with the country of origin's formalities. As a result, the 1908 Berlin revision prohibited the imposition of formalities on foreign authors altogether, although member states remained free to require that domestic authors affix notice, register claims and/or deposit copies with local authorities. ${ }^{42}$ And, to ensure that an author's failure to carry out domestic formalities - with a consequent loss of protection in the country of origin-would not affect the availability of international protection, the Berlin revisers specified that 'apart from the provisions of this Convention, the extent of protection, as well as the means of redress afforded to the author to protect his rights, shall be governed exclusively by the laws of the country where protection is claimed' ${ }^{43}$ The effect of this language was to confer copyright through the Berne Union, automatically and upon creation, on every conventioncovered work created by an author who was a national of a Berne Union member state, or first published within a member state. The Berne Union today is composed of 166 member states, including the United States, of which I am a national. ${ }^{44}$ As a result of the Berlin revision, the moment I created this essay, it enjoyed copyright protection in each of those 166 countries, without any obligation that I fill out any forms or pay any registration fees to authorities in any one of those countries. This is indeed the universal coverage for which Dickens and Mill in 1858 and Victor Hugo and Ivan Turgenev in 1878 yearned.

\section{CLASH OF UTOPIAS: UNIVERSAL LIBRARY OR UNIVERSAL BOOKSTORE?}

This brings us to the clash of universalist aspirations; how can 'all the world's knowledge ${ }^{95}$ including that expressed in works whose copyrights have not expired, be delivered, on demand, to users anywhere in the world (with Internet access), if the

${ }^{41}$ Rukettson \& Ginsburg (2006), para. 2.13.

${ }^{42}$ Ibid., para. 3.12.

${ }^{43}$ Berne Convention, art. 5(2).

${ }^{44}$ For the list of members, see http://www.wipo.int/export/sites/www/treaties/en/documents/pdf/berne. pdf (accessed 29 April 2013).

${ }^{45}$ The phrase is one of Google's slogans, and thus brings us also to Larry (Page) and Sergey (Brin), the storied computer scientists who founded Google in 1998 while graduate students at Stanford University. See http:// www.google.com/about/company/facts/management/ (accessed 29 April 2013). 
copyrights of the creators and publishers of those works are supposed to exist and be enforceable almost everywhere in the world?

You may by now be familiar with the general outlines of the Google book-scanning program, inaugurated in $2004 .{ }^{46}$ Google scanned the contents of participating US university libraries, one of which, the University of Michigan, authorised Google to reproduce and to store digital copies of in-copyright works (the other libraries had restricted Google's scanning to their public domain collections). The scanned text was converted to a searchable format, allowing users to query Google's database and retrieve, in addition to basic bibliographic information, two-to-three line 'snippets' of text setting the searched term in its immediate textual context. Google would not display a greater amount of text without agreement from the rightholders. But Google did, and does, retain complete copies of millions of the in-copyright scanned books in its database. Google also returned to each participating library a fully scanned copy of that library's holdings.

In 2005 the Authors Guild brought a class action on behalf of thousands of authors ${ }^{47}$ and a group of publishers brought a separate action against Google alleging massive copyright infringement through the copying and storage of full text and the communication to the public of 'snippets' of text. Google boldly replied that the US 'fair use' exception to copyright ${ }^{48}$ sheltered its program, and all the parties began settlement negotiations. In 2011, the federal district court for the Southern District of New York declined to approve the class action settlement, largely because the solution the settlement would have put in place was more appropriate for legislative rather than judicial determination, and because of the insuperable advantage the settlement would have conferred on Google relative to competitors who sought permission before scanning in-copyright books. As the court stated:

Google engaged in wholesale, blatant copying, without first obtaining copyright permissions. While its competitors went through the 'painstaking' and 'costly' process of obtaining permissions before scanning copyrighted books, 'Google by comparison took a shortcut by copying anything and everything regardless of copyright status.' As one objector [to the settlement] put it: 'Google pursued its copyright project in calculated disregard of authors' rights. Its business plan was: "So, sue me."”49

\footnotetext{
${ }^{46}$ For background, see generally Samuelson (2010: 1308-74); Samuelson (2011: 479-562).

${ }^{47}$ The outcome of a class action binds all similarly situated members of the class who do not initially opt out of the litigation. See Fed. R. Civ. P. 23.

${ }^{48}$ See 17 U.S.C. $§ 107$.

${ }^{49}$ Authors Guild v. Google, Inc., 770 F. Supp. 2d 666, 679 (S.D.N.Y. 2011) (citations omitted).
} 


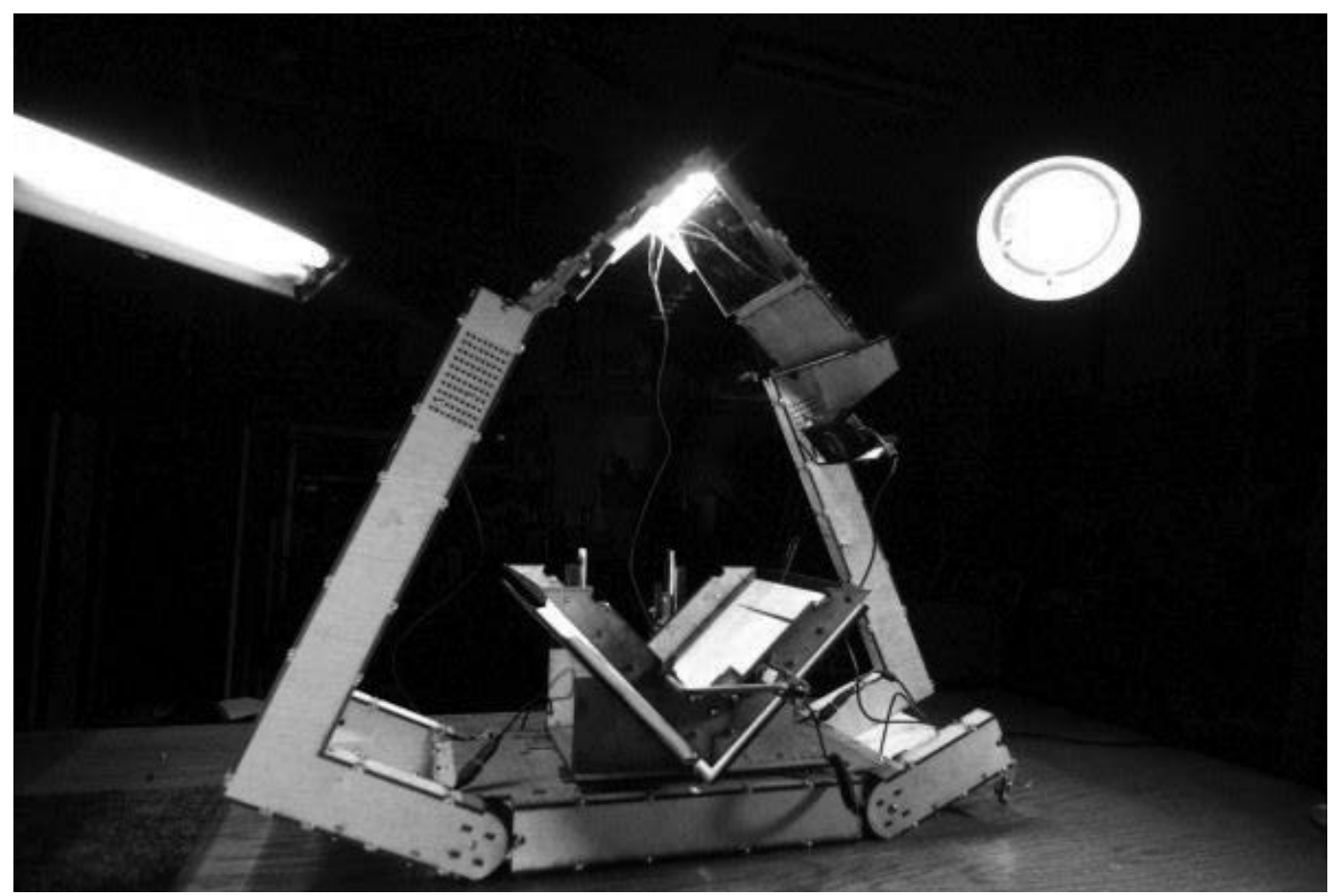

Figure 5: Otlet's spiritual descendants benefit from more powerful and more participatory technology. Consider this modern, inexpensive 'Open Hardware Book Scanner' for 'do-it-yourselfers'. Google's high-volume scanning depends upon conceptually similar, albeit more industrial, scanners. (Source: Dan Reetz. See http://www.diybookscanner.org/. (The photographer has dedicated the image to the public domain, see http://www.danreetz.com/blog/2009/10/12/public-domain-images-of-theportable-book-scanner/.))

Since the court's rejection of the class action settlement, Google has reached a separate settlement with the publishers, but the terms are undisclosed. ${ }^{50}$ The authors' class action continues. ${ }^{51}$

Had the class action settlement been approved, it might, at least in the short run, have approximated the Alexandrian aspirations of the Internet-enabled, because, in addition to generally providing full text copies of copyright-expired works (as to which Alexandria may already have been achieved), it would have offered various levels of access to in-copyright books. For copyright-protected books not commercially available (out of print), users would have seen up to 20 per cent of the text under the standard preview. ${ }^{52}$ Moreover, users could have viewed full text of in-copyright but out-of-print works through universities and libraries who would have obtained insti-

\footnotetext{
${ }^{50}$ Miller (2012: B7).

${ }^{51}$ The second Circuit recently reversed the District Court's certification of the class action, remanding for a determination of the merits of Google's fair use defence. See The Author's Guild, Inc. v. Google. Inc., Docket No. 12-3200-cv (2d Cir. 1 July 2013).

${ }^{52}$ Samuelson (2010: 1316).
} 
tutional subscriptions from Google. And users could have viewed full books under a special Public Access Service provided free to public libraries and to not-for-profit higher education institutions at a specified number of terminals. ${ }^{53}$ Thus, Google would have partnered with libraries (not just the libraries whose collections Google scanned) to give the public access to the entire contents of in-copyright out-of-print works.

So where's the rub? Google is not an eleemosynary institution. Robert Darnton, the noted historian and University Librarian at Harvard University, doubtless expressed the fears of many institutional librarians when he cautioned that the price of the institutional subscription may rise precipitously, putting libraries in the same kind of pricing stranglehold they complain of today regarding the scientific journal publishers. ${ }^{54}$

Moreover, with or without the class action settlement, the level of access via libraries or online bookstores to commercially available in-copyright books (principally, current titles) depends on agreements with the rightholders. If an author or publisher wishes to make her work freely available, for free (or against advertising revenue), she may do so, with or without Google. And rightholders who want to be paid have authorised Google (and Amazon, and Barnes \& Noble, etc.) to sell eBook versions of incopyright titles; indeed they were doing so even before Google began its massive unauthorised scanning. As to current titles, then, the market for electronic access via Google or others is well under way.

But what about libraries? Many rightholders may be reluctant to make their works available for unremunerated library access if that access is likely to compete with commercialisation of the book. Yet were libraries to take full advantage of the capacities of digital media, the competition would be apparent. In the hardcopy world, only one reader can consult a copy at a time, and the reader must travel to the library, even if she borrows the book to read at home. So while some library patrons may borrow books instead of purchasing them, there is too much 'friction' in the process for library lending to substitute for book sales generally. In the digital environment, by contrast, libraries could, as a matter of technology, make the book available simultaneously to all interested readers, accessing from anywhere in the world. As a matter of law, however, such broad distribution would require the copyright holders' authorisation.

Partnering with for-profit Google (and Amazon, and Barnes \& Noble, etc.) to exploit remote access to full or partial text can support a business model for authors and publishers. By contrast, it is not a university or public library's mission to sell access to books. But the line between book lending and book selling may be blurring. The President of the American Library Association concedes that '[i]n varied ways, libraries serve as marketers of books in all their forms' ${ }^{55}$ That Association, in an open letter complaining of some US publishers' reluctance to authorise libraries to distribute eBooks, held out this palm:

\footnotetext{
${ }^{53}$ Ibid., p. 1317.

${ }^{54}$ Darnton (2012: 6, 15).

${ }^{55}$ Sullivan (2012a).
} 
$[\mathrm{H}]$ undreds of publishers of ebooks have embraced the opportunity to create new sales and reach readers through our nation's libraries. One recent innovation allows library patrons to immediately purchase an ebook if the library doesn't have a copy or if there is a wait list [that the library patron] would like to avoid. ${ }^{56}$

The technology also prompts additional schemes that could be fruitful, or unethical, depending on your perspective. What if, instead of or along with providing a platform for book sales, the library's website hosted advertising, whose revenue went to the copyright holders? What if the library made 100 per cent of the book available for free for onsite consultation (in effect treating the digital book like a hardcopy) but only 20 per cent of the book available for free remotely, together with a link to the publisher's webpage so that remote readers could purchase fuller access?

In considering ways in which libraries might alleviate competition with publishers, we have been assuming that, given the choice between free and paid access, the public will prefer the former. But the assumption turns on equivalent levels of access. If copyright holders limit the level of free remote access that libraries may provide, but publishers make full text available for a fee (or against advertising revenue), the commercial option may seem more attractive. I suspect that, especially among the members of this august Academy, I am not alone in having occasionally to point to physical books to remind students that they might need to go to the library to consult these artefacts because not everything is available on the Net. As publishers or other intermediaries increase the offer of eBooks, if they do not also authorise libraries to offer remote access, the library's public may shrink to vintage scholars intoxicated by the smell of ageing paper.

Lest one think that the posited hybrid digital library/bookstore is fanciful, let's return to Google. The original book-scanning project has evolved. Google now offers the 'Google Books Library Project'. In Otletian back-to-the-future fashion, the project is subtitled '[a]n enhanced card catalog of the world's books' ${ }^{57}$ It offers full text of public domain books. And limited (or no) views of in-copyright books (these restrictions may reflect the undisclosed terms of the settlement with the publishers). The 'library project' also includes links to online bookstores to buy the book. The future Alexandrian repository of digitised books therefore may take many forms, not all of them in line with the original public curator-custodian model.

Whether public or private, however, Alexandria's virtual shelves need to be stocked with more than public domain works and current eBooks. The difficulties arise from books still in copyright, but which their authors or publishers are no longer making available, whether commercially or for free. The copyright term is very long - in many

\footnotetext{
${ }^{56}$ Sullivan (2012b).

${ }^{57}$ See http://books.google.com/googlebooks/common.html (accessed 29 April 2013).
} 
countries including the $\mathrm{US}^{58}$ and those of the EU, ${ }^{59}$ it endures for 70 years after the author's death — but books' commercial life generally is far shorter. For the vast bulk of books, copyright owners may after five or ten years have exhausted a hardcopy book's likely revenue stream. I specify hard copy, because a book in digital form can be offered on demand, so a publisher may keep it commercially available for individualised delivery, and thus take advantage of the persistent trickle of sales the 'long tail' phenomenon promises for 'backlist' works once they have been digitised and made available to the public. As a result, the problem of 'unavailable books' may be transitional, but for now there are undoubtedly millions of out-of-print in-copyright books existing only in hardcopy format.

How are these works to be digitised? Conversion to digital format is the prerequisite to bringing these works under the aegis of the virtual Library of Alexandria, but it is not clear who can or will exercise the rights to scan and store (unless you're Google, and just go ahead and do it anyway). With respect to publishers, we can anticipate at least two problems. First, lack of economic incentive to commit the resources to scanning all the in-copyright books they ever published (though these costs may constantly be decreasing). Second, and more significantly, for older books, the rights may have reverted to the authors, or the publisher may never have acquired the digital rights, and therefore, without reaching a new agreement with the author, the publisher can't unilaterally digitise or authorise third parties to do so.

What about authors? In addition to the resource problem, the older the book is, the harder the author or her heirs may be to find. And depending on the competent national law, if the author is dead, it may be necessary to obtain a majority or even unanimity of the heirs' agreement.

What about libraries? If the book is already in the library's collection, some national laws may allow the library to digitise for preservation. But it is less clear that the library could digitise to make available on the scale our Alexandrian project envisions. Could the library take a leaf from Google's book and just digitise and disseminate anyway? Absent an applicable copyright exception, that conduct would plainly be infringing. And despite some rather heated copyright-bashing rhetoric of late, ${ }^{60}$ libraries generally are very law-abiding citizens.

$* * *$

What might an applicable exception look like? On 25 October 2012, the EU promulgated the 'Orphan Works' Directive, which instructs member states to enact

${ }^{58} 17$ U.S.C. $\S 302$.

${ }^{59}$ Council Directive 93/98/EEC of 29 Oct. 1993 Harmonizing the Term of Protection of Copyright and Certain Related Rights, art. 1.

${ }^{60}$ For instance, the university librarian of my home institution, Columbia University, foresees 'hard ball' between libraries and what he once labelled 'a copyright axis of evil'. Neal (2011: 170, 172); Neal (2002: 48). 
copyright exceptions allowing public libraries to digitise and make available books and periodicals and related works in their collections, if the rightholders cannot be found following a diligent search. ${ }^{61}$ If the rightholder subsequently turns up, the work's 'orphan' status will end, and the rightholder will be entitled to fair compensation for past exploitations. ${ }^{62}$ Importantly, the directive provides that a work deemed 'orphaned' following a diligent search in its EU country of origin will be considered 'orphaned' in all other EU member states. ${ }^{63}$

Does the Orphan Works Directive pave a digital path to Alexandria? Probably not. First, we do not know how significant is the universe of rightholders for books and periodicals who cannot be found following the requisite diligent search. If anything, as suggested earlier, there may be too many potential rightholders. Second, the diligent search requirement does not lend itself to mass digitisation since it implies individualised inquiry and accordingly high transaction costs. Google Books demonstrates the point. When Google massively scanned the books in the University of Michigan library, it did not search (diligently or otherwise) for copyright owners. Rather, it offered copyright owners an 'opt-out' solution: if the copyright owner did not want its books to be in the Google Books program, it could tell Google, and Google would block views of the books. Opt-out approaches favour the proposed use, but, as the US Justice Department and the district judge who rejected the Google Books class action settlement stressed, they turn copyright on its head. ${ }^{64}$ As a system of exclusive rights, copyright generally obliges exploiters to ask permission first.

Legislatures, however, can depart from the exclusive rights default, at least as a matter of domestic law. Several countries are considering measures that would permit mass digitisation subject to payment to a collecting society, and subject to the author or publisher's opt-out. ${ }^{65}$ Because these laws or proposals do not limit the beneficiaries of these mass digitisation authorisations to non-profit libraries, the breadth of their application may be problematic. But suppose a more modestly tailored library digitisation exception: what should it look like?

\footnotetext{
${ }^{61}$ Directive 2012/28/EU of 25 Oct. 2012 on Certain Permitted Uses of Orphan Works.

${ }^{62}$ Ibid., art. 5, 6(5).

${ }^{63}$ Ibid., art. 4.

${ }^{64}$ Authors Guild v. Google, Inc., 770 F. Supp. 2d 666, 680-82 (S.D.N.Y. 2011); Statement of Interest of the United States of America Regarding Proposed Class Settlement at 11 n. 3, Authors Guild (Sept. 18, 2009) (No. 05 Civ. 8136 (DC)), ECF No. 720, 2009 WL 3045979.

${ }^{65}$ France has enacted such a law, see Law No. 2012-287 of 1 March 2012 concerning the digital exploitation of unavailable 20th-century books, codified at Code of intellectual property art. L134. See also UK Enterprise and Regulatory Reform Act 2013 s79 (orphan works and extended collective licensing). See generally, US Copyright Office, Legal Issues in Mass Digitization: A Preliminary Analysis and Discussion Document (October 2011), http://www.copyright.gov/docs/massdigitization/USCOMassDigitization_ October2011.pdf.
} 
As a first principle (with which many may not agree), libraries should not compete with publishers, or for that matter with self-publishing authors. Ascertaining what 'compete with' means, of course, is not an obvious endeavour. We might take library-publisher coexistence in the hardcopy world as a starting point, but it seems a waste to replicate the physical limitations of that world in the digital environment. On the other hand, the digital world also offers opportunities for individualised commercialisation of the 'back list' of books (or portions of books) in ways that free remote delivery by libraries might compromise, so it may be necessary to limit the number of simultaneous remote readers.

Second, the exception should favour the creation of otherwise unavailable digitised versions. As the publishers' agreement with Google suggests, it is possible to cover some of the universe of extant hardcopies by negotiated agreements (albeit not necessarily negotiated with libraries). The older the book, however, the more elusive a negotiated solution because the necessary parties may not be around to be represented. A 'moving wall' at the back end of the copyright term, as Professor Darnton has suggested, may offer an appealing application of the opt-out technique, allowing public libraries both to digitise and to disseminate during the last years of the copyright term, subject to objection by copyright holders ${ }^{66}$ Moreover, for countries with 'life +70 ' copyright terms, imposing an opt-out solution for the last twenty years would not contravene Berne Convention norms, because the conventional copyright term is 'life +50 ' ${ }^{67}$ Fifty years post mortem auctoris is, nonetheless, a very long time, and so an opt-out approach, perhaps combined with statutory remuneration, is worth considering in order to enable public libraries to make the digital books available remotely for some greater portion of the post-mortem copyright term.

Third, for any exception that includes statutory remuneration, authors (or their heirs) should be the recipients. The law should presume that, in the absence of proof by the publisher that it holds digital rights (in whole or in part), the money should go to the author.

\section{CONCLUSION}

The digital era is bringing us a convergence of the functions of library and of publisher. The blurring of their roles has prompted some, notably the French legislature, ${ }^{68}$ to panic that Google has gained an unfair advantage in the digital book market. Accordingly, there is the risk of a race to catch up, by too quickly passing laws to

\footnotetext{
${ }^{66}$ Darnton (2012: 16-17).

${ }^{67}$ Berne Convention (1979), art. 7.

${ }^{68}$ See Law No. 2012-287 of 1 March 2012 (see above, n. 65).
} 
facilitate mass digitisation, not necessarily to the benefit of libraries, nor of authors. We do not need hastily cobbled copyright legislation that simply transposes the sloganeering that has poisoned the public debates over copyright. Whether in international, EU or national fora, much of the discourse in the copyright field has been hair-rendingly dismal. We need to leave off the Manichean posturing in general, and in particular to endeavour carefully to work through the respective domains of copyright holders and public libraries, so that free public, digital, libraries may continue to develop, and also so that authors may reap the benefits both of broad dissemination and commensurate remuneration.

\section{Acknowledgements}

Many thanks for expert research assistance to John Briggs and Philip Sancilio, both Columbia Law School class of 2013. Thanks also to William R. Cornish, and Lionel Bently, respectively Hershel Smith Professor emeritus, and Hershel Smith Professor, University of Cambridge, to Jean-Paul Trialle for introducing me to the Mundaneum, and to June Besek, Executive Director of the Kernochan Center for Law, Media and the Arts at Columbia Law School. I am grateful for suggestions and overall inspiration to George T. Spera, Jr.

\section{REFERENCES}

Austin, G.W. \& Zavidow, A.G. (2008), 'Copyright Law Reform Through a Human Rights Lens', in P.L.C. Torremans (ed.), Intellectual Property and Human Rights (Alphen aan den Rijn, Netherlands), pp. 257-85.

Bagnall, R.S. (2002), 'Alexandria: Library of Dreams', Proceedings of the American Philosophical Society, 146; 348-62.

Barnes, R. (2000), 'Cloistered Bookworms in the Chicken-Coop of the Muses: The Ancient Library of Alexandria', in R. MacLeod (ed.), The Library of Alexandria: Centre of Learning in the Ancient World (London), pp. 61-77. PMid:10757062.

Bivens-Tatum, W. (2012), Libraries and the Enlightenment (Los Angeles).

Bush, V. (1945), 'As We May Think', Atlantic Monthly (July), 101-8, at p. 106.

Canfora, L. (1989), The Vanished Library, trans. M. Ryle (London).

Chartier, R. (1993), 'Libraries Without Walls', Representations, 42; 38-52. http://dx.doi.org/10.1525/ rep.1993.42.1.99p01621.

Darnton, R. (2012), 'Digitize, Democratize: Libraries and the Future of Books', Columbia Journal of Law \& the Arts, 36; 1-19.

Doni, A.F. (1550a), La libraria del Doni fiorentino. Nella quale sono scritti tutti gl'autori vulgari con cento discorsi sopra quelli. Tutte le tradutioni fatte all'altre lingue, nella nostra \& una tavola generalmente come si costuma fra librari (Venice) (Censimento nazionale delle edizioni italiani del XVI secolo catalogue number CNCE 17682).

Doni, A.F. (1550b), La libraria del Doni fiorentino. Nella quale sono scritti tutti gl'autori vulgari con cento discorsi sopra quelli. Tutte le traduttioni fatte dall'altre lingue, nella nostra \& una tavola generalmente 
come si costuma fra librari. Di novo ristampata, corretta, \& molte cose aggiunte che mancavano (Venice) (CNCE 17683).

Doni, A.F. (1557), La libraria del Doni fiorentino, divisa in tre trattati. Nel primo sono scritti, tutti gli autori volgari, con cento \& piu discorsi, sopra di quelli. Nel secondo, sono dati in luce tutti i libri, che l'autore ha veduti a penna, il nome de' componitori, dell'opere, i titoli, \& le materie. Nel terzo, si legge l'inventione dell'academie insieme con i sopranomi, i motti, le imprese, \& l'opere fatte da tutti gli academici. Libro necessario, \& utile, a tutti coloro che della cognitione della lingua hanno bisogno, \& che vogliono di tutti gli autori, libri, \& opere sapere scrivere, \& ragionare (Venice) (CNCE 17701).

Doni, A.F. (1580), La libraria del Doni fiorentino; nella quale sono scritti tutti gli autori volgari, con cento discorsi sopra quelli; tutte le tradottioni fatte dall'altre lingue, nella nostra, \& una tavola generale, come si costuma fra librari. Opera utile a ciascuno che si diletta della lingua volgare, et che desidera fornire uno studio di libri, composti in essa lingua; di nuovo ristampata, \& aggiuntiui tutti i libri volgari posti in luce da trenta anni in qua, \& levatone fuori tutti gli autori, \& libri prohibiti (Venice) (CNCE 17717).

Dzielska, M. (1995), Hypatia of Alexandria, trans. F. Lyra (Cambridge, MA).

Feather, J. (1994), Publishing, Piracy and Politics: An Historical Study of Copyright in Britain (London).

Gasaway, L.N. (2003), 'America's Cultural Record: A Thing of the Past?', Houston Law Review, 40; $643-71$.

Ginsburg, J.C. (2013), 'Proto-Property in Literary and Artistic Works: 16th-Century Papal Printing Privileges', Columbia Journal of Law \& the Arts, 36; 345-458.

Goldschmidt, R. \& Otlet, P. (1906), Sur une forme nouvelle de livre: Le Livre microphotographique.

Helfer, L.R. \& Austin, G.W. (2011), Human Rights and Intellectual Property: Mapping the Global Interface (Cambridge).

Heller-Roazen, D. (2002), 'Tradition's Destruction: On the Library of Alexandria', October, 100; $133-53$.

Johns, A. (2009), Piracy: The Intellectual Property Wars from Gutenberg to Gates (Chicago: University of Chicago Press).

Lieber, F. (1840), On International Copyright, in a Letter to the Hon. William C. Preston, Senator of the United States (New York), pp. 21-2, 25.

Miller, C.C. (2012), 'Google Deal Gives Publishers a Choice: Digitize or Not', New York Times, 5 Oct.; p. B7.

Neal, J.G. (2002), 'Copyright Is Dead . . Long Live Copyright', American Libraries (Dec.); 48-51.

Neal, J.G. (2011), 'Fair Use is Not Civil Disobedience: Rethinking the Copyright Wars and the Role of the Academic Library', in D.M. Mueller (ed.), Declaration of Interdependence: The Proceedings of the ACRL 2011 Conference, March 30-April 2, 2011, Philadelphia, PA (Chicago), pp. 168-73.

Otlet, P. (1934), Traité de documentation: Le Livre sur le livre, théorie et pratique (Brussels).

Otlet, P. (1935), Monde: Essai d'universalisme (Brussels).

Partridge, R.C.B. (1938), The History of the Legal Deposit of Books Throughout the British Empire (London).

Pfister, L. (2005), 'La propriété littéraire est-elle une propriété? Controverses sur la nature du droit d'auteur au XIXe siècle', Revue internationale du droit d'auteur, 205 (July); 117-209.

Raymond, W.B. (1990), International Organisation and Dissemination of Knowledge: Selected Essays of Paul Otlet (Amsterdam).

Ricketson, S. \& Ginsburg, J.C. (2006), International Copyright and Neighbouring Rights: The Berne Convention and Beyond, 2nd edn, vol. 1 (Oxford).

Romberg, M.É. (1859), Compte rendu des travaux du Congrès de la Propriété Littéraire et Artistique, vol. 1 (Brussels).

Samuelson, P. (2010), 'Google Book Search and the Future of Books in Cyberspace', Minnesota Law Review, 94; 1308-74. 
Samuelson, P. (2011), 'The Google Book Settlement as Copyright Reform', Wisconsin Law Review; 479-562.

Seidell, A. (1939), 'Microfilm Copying of Scientific Literature', Science, n.s. 89; 219-20.

Société des Gens de Lettres de France, (1879), Congrès Littéraire International de Paris 1878 (Paris).

Sullivan, M. (2012a), 'Libraries and Publishers Strengthening The E-Reading Ecosystem' (American Library Association E-Content Blog, 27 Sept.). http://americanlibrariesmagazine.org/e-content/ libraries-and-publishers-strengthening-e-reading-ecosystem.

Sullivan, M. (2012b), 'An Open Letter to America's Publishers' (American Library Association, 28 Sept.). http://www.ala.org/news/pr?id=11508.

US Copyright Office, Legal Issues in Mass Digitization: A Preliminary Analysis and Discussion Document (October 2011),

http://www.copyright.gov/docs/massdigitization/USCOMassDigitization_October2011.pdf

The author: Jane C. Ginsburg is the Morton L. Janklow Professor of Literary and Artistic Property Law at Columbia University School of Law and Faculty Director of its Kernochan Centre for Law, Media and the Arts. Her works on copyright law include Copyright: Concepts and Insights (with Robert A. Gorman) (Foundation Press 2012).

Contact: ginsburg@1aw.columbia.edu

This article is licensed under a

Creative Commons Attribution-NonCommercial-NoDerivs 3.0 Unported License.

Journal of the British Academy (ISSN 2052-7217) is published by

The British Academy - the national academy for the humanities and social sciences. 10-11 Carlton House Terrace, London, SW1Y 5AH

www.britac.ac.uk 